\title{
PEMBINAAN TK/TPA
}

\section{YUNI SARAH}

NIM: 9173490410010

Email: yunisarahyunsa@gmail.com

\section{Bentuk Kegiatan}

- Ikut serta dalam pengajaran santriwan dan santriwati

\section{Lokasi}

- Rumah imam dusun

\section{Hari/Tanggal dan Waktu}

Senin sampai Sabtu,(terhitung dari rabu 23 september 2020).

\section{Peserta yang Dilibatkan}

- Santriwan dan santriwati

- Mahasiswa KKLP STIE STKIP YAPTI

\section{Alasan Diadakannya}

Untuk menanamkan rasa cinta santri kepada Al-Quran.

\section{Tujuan dan Manfaat}

Meningkatkan kemampuan bacaan AlQuran dan menjujung tinggi normanorma keagamaan

\section{Deskripsi Kegiatan}

Kegiatan pembinaan ini mulai berlangsung pada tanggal 23 September 2020 dan kami mengagendakan untuk berlangsung sampai 2 bulan kedepan. Jarak dari posko menuju lokasi TK/TPA sangat dekat sehingga kami menjangkaunya dengan berjalan kaki. 


\section{Referensi Wajib}

- HERIANTO, H., \& Amir, A. S. (2020, September 23). Pedoman Pelaksanaan Kuliah Kerja Lapangan Plus (KKLP) Mahasiswa STIE dan STKIP YAPTI Jeneponto. https://doi.org/10.31219/osf.io/7dvpk 


\title{
OBSERVASI LINGKUNGAN DI SETIAP DUSUN DI DESA GANTARANG
}

\author{
YUNI SARAH \\ NIM: 9173490410010 \\ Email: yunisarahyunsa@gmail.com
}

\section{Bentuk Kegiatan}

- Kunjungan ke dusun-dusun se desa Gantarang selama 4 hari

- Penentuan program kerja yang akan dipaparkan dalam seminar program kerja desa Gantarang

\section{Lokasi}

- Dusun Sunggumanai

- Dusun Bonto Biraeng

- Dusun Bonto Marannu

- Dusun Gantarang Buleng

- Dusun Bontonompo

- Dusun Maccini Baji

- Dusun Bonto Baru

\section{Hari/Tanggal dan Waktu}

Rabu, 16 September 2020

- Dusun Sunggu Manai (09.00 WITA)

- Dusun Bonto Biraeng (13.30 WITA)

- Dusun Bonto Marannu ( 15.30 WITA)

Kamis, 17 September 2020

- Dusun Gantarang Buleng (09.00 WITA)

- Dusun Bontonompo (13.00 WITA)

- Dusun Maccini Baji (15.30 WITA)

Jum'at, 18 September 2020

- Bonto Baru (08.00 WITA)

\section{Peserta yang Dilibatkan}

- Kepala Dusun Desa Gantarang

- Masyarakat

- Mahasiswa(i) STIE STKIP YAPTI JENEPONTO

\section{Alasan Diadakannya}

Alasan diadakannya observasi ini adalah untuk mengetahui apa saja yang akan menjadi program kerja kami selama dua bulan ke depan. Selain itu, tujuan observasi ini adalah untuk lebih mendekatkan tali silaturrahmi diantara masyarakat dengan mahasiswa KKLP yang awalnya belum saling kenal mengenal, bisa menjadi saling mengenal.

\section{Tujuan dan Manfaat}

Observasi atau kunjungan ini bermanfaat lebih memberi kami informasi mengenai desa Gantarang dan lebih saling mengenal dengan masyarakat setempat.

\section{Deskripsi Kegiatan}

Kegiatan observasi ini dimulai pada jam 09.00 di hari pertama berada di desa Gantarang. Kami melakukan observasi ini dengan berjalan kaki untuk dusun-dusun yang letaknya tidak jauh dari posko kami tapi untuk dusun-dusun yang letaknya jauh 
